Bull. Geol. Soc. Finland 41, 93-98 (1969)

\title{
A STUDY OF ISOTROPIC-PSEUDOANISOTROPIC ZONING IN SPHALERITE
}

\author{
Ilmari HaApala and Kauko LaAjoki \\ Geological Survey of Finland, Otaniemi
}

\begin{abstract}
Sphalerite with isotropic-pseudoanisotropic zoning is described from greisen in Eurajoki, SW Finland. Singlecrystal X-ray studies showed that the pseudoanisotropy is due to very small chalcopyrite inclusions, oriented with their crystallographic axes parallel to the sphalerite axes. Electron probe microanalyses are presented for the isotropic central part and for the pseudoanisotropic marginal zone of a sphalerite crystal. The main chemical difference between the zones is that the FeS content (19.2 mole per cent) of the central part is essentially replaced by $\mathrm{CuFeS}_{2}(12.1$ mole per cent) in the marginal zone. The zonal structure is interpreted to be of secondary origin.
\end{abstract}

\section{Introduction}

In the summer of 1967, the Geological Survey of Finland was prospecting for tin in Eurajoki, SW Finland. When studying the discovered mineralized occurrences, attention was drawn to the unusual sphalerite occurring in two greisens and associated veintles. In polished section this sphalerite appeared strongly anisotropic with crossed nicols. One of the greisens is located in the highway intersection about 1.7 kilometers north of the Eurajoki church, the other near the farm Santa-Alho in the village of Lapijoki. The country rock is in both cases an even-grained variety of rapakivi granite known as "Tarkki granite». This granite contains as chief minerals quartz, orthoclase, partly altered plagioclase, hornblende and/or chlorite. The accessory minerals are fayalite, ilmenite, magnetite, apatite, danalite, zircon, fluorite, pyrite and perrierite (or chevkinite). The sphalerite in the greisen near Santo-Alho is thoroughly "anisotropic», whereas that near the Eurajoki church is often zoned with isotropic and manisotropic» areas. These sphalerites are structurally very similar with the pseudoanisotropic sphalerites described by Janković (1957) and Maucher and Rehwald (1962). These authors explain that the apparent anisotropy is due to very finegrained oriented chalcopyrite inclusions in sphalerite. Obviously very similar pseudoanisotropic sphalerite is also described by Saksela (1951, p. 192) from Pitkäranta, Russian Karelia, in which case it is explained as an intergrowth of sphalerite and very fine-grained cubanite. Also Ramdohr (1960) mentions that sphalerite may be strongly (pseudo-)anisotropic due to very small exsolutions. The authors mentioned have obviously made their observations and drawn their conclusions with the aid of ore microscopic 


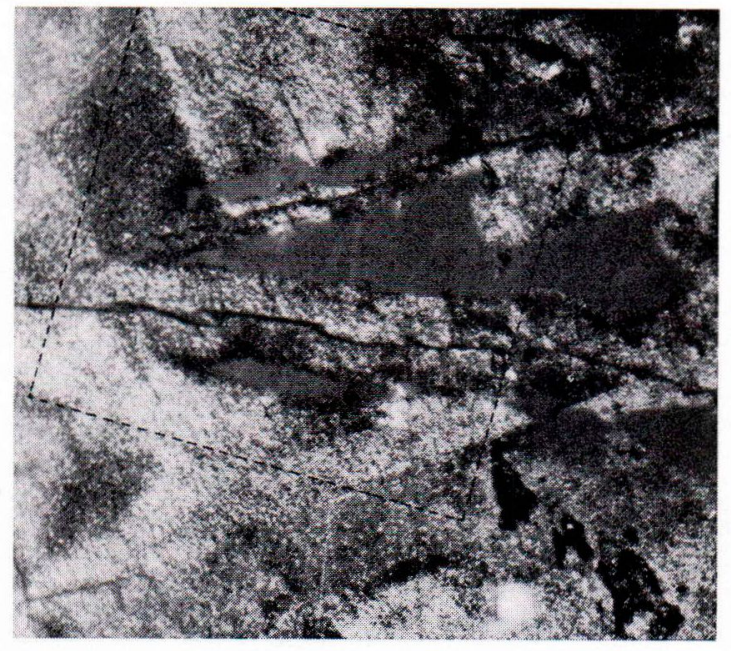

Fig. 1. Pseudoanisotropic sphalerite surrounding and veining isotropic sphalerite. Eurajoki. Specimen 204A/ $\mathrm{IH} / 67$. Polished section, crossed nicols. Magn. $400 \times$

studies. The present authors have also used single-crystal X-ray studies and an electron microprobe in studying the isotropic-pseudoanisotropic zoning in the Eurajoki sphalerites. The microprobe analyses were performed by Kauko Laajoki. The other mineralogical studies in the field and in the laboratory were done by Ilmari Haapala, who also compiled the manuscript.

\section{Ore microscopy}

The greisen near the Santa-Alho farm contains as ore minerals chalcopyrite, pseudoanisotropic sphalerite, stannite, rutile, cassiterite, covelline and ilmenite. The greisen-bordered veinlet north of the Eurajoki church contains, besides chalcopyrite, zoned sphalerite, pyrite, marcasite, covelline, galena, native bismuth and secondary iron oxide as ore minerals. Also some cassiterite occurs in the greisen proper. Bismuth is encountered as an inclusion in the sphalerite. In both occurrences the sphalerite crystals are often surrounded and veined by chalcopyrite. As gangue

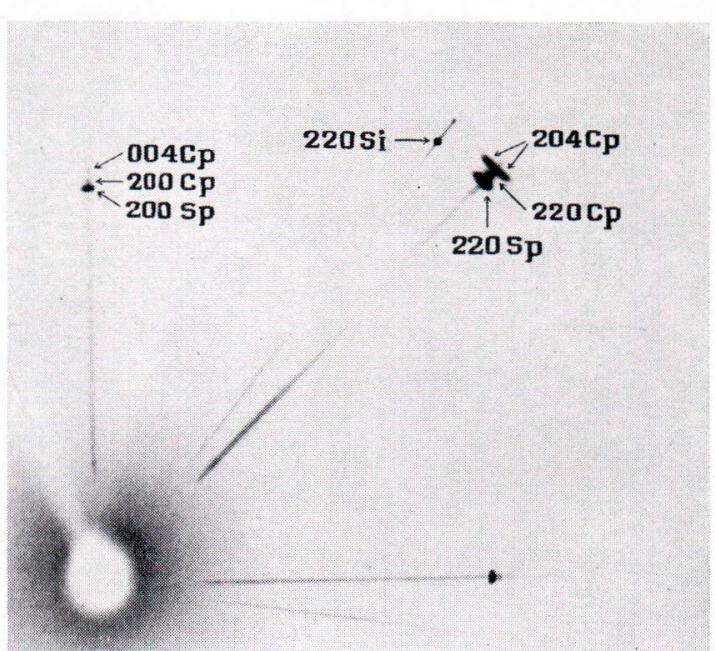

Fig. 2. Part of an $a$-axis zero-level precession photograph of the pseudoanisotropic sphalerite showing the orientation of the very small chalcopyrite inclusions. Silicon 220 type reflections as standard. Instrument settings: Ni-filtered $\mathrm{Cu}$ radiation, $\mu=25^{\circ}$. Sp sphalerite; $\mathrm{Cp}$ chalcopyrite; Si silicon.

minerals both greisens contain quartz, mica, fluorite and potash feldspar (triclinicity variable, max. 0.75). The sphalerite north of Eurajoki is often zoned in a way similar to that depicted by Maucher and Rehwald (1962). The marginal zones of the crystals are pseudoanisotropic and the central parts isotropic. Small sphalerite crystals, especially those in contact with the chalcopyrite in the central quartz-feldspar-chalcopyrite veinlet, are thoroughly pseudoanisotropic, whereas the larger crystals are usually zoned. However, some sphalerite crystals which are located in the greisen proper and are not surrounded by chalcopyrite are entirely isotropic or have only a very narrow pseudoanisotropic marginal zone. On the other hand, some large sphalerite crystals (grain size up to $3-4 \mathrm{~mm}$ ), which are surrounded, densily veined and partly replaced by chalcopyrite in the central veinlet, are thoroughly pseudoanisotropic. Sometimes the pseudoanisotropic sphalerite intersects the isotropic central part as veins along fissures (Fig. 1). The zone borders are quite sharp. They can be observed also with one nicol. The pseu- 


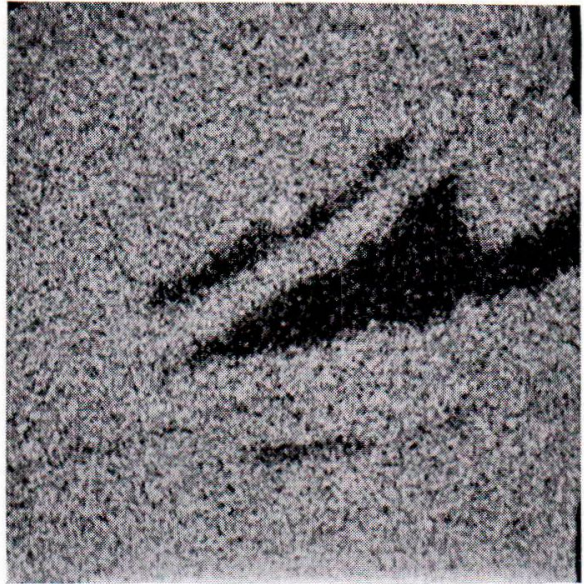

$\mathrm{CuK} \alpha$

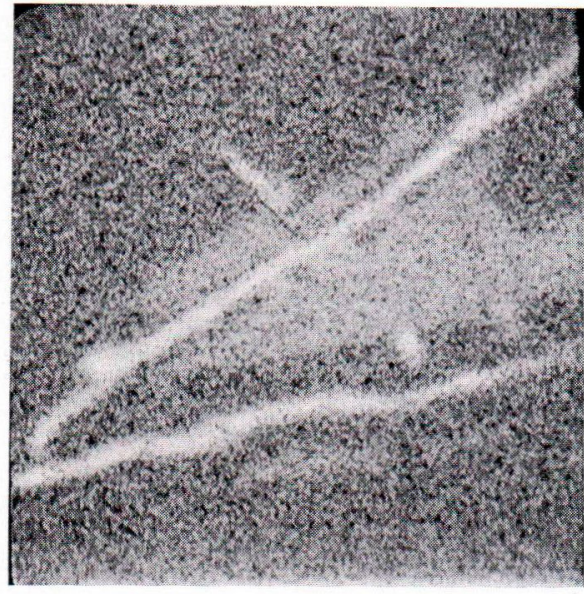

$\mathrm{FeK} \alpha$

Fig. 3. Electron probe scanning pictures sgowing the distribution of $\mathrm{Cu}$ and $\mathrm{Fe}$ in a part of the sphalerite crystal seen in Fig. 1 (Bounded with a broken line). Magn. $500 \times$.

doanisotropic zones are a little darker than the isotropic areas. With crossed nicols the zones are emphasized, as are also the twin lamellae. The colour of the pseudoanisotropic sphalerite is ink blue with crossed nicols.

With a smaller magnification the pseudoanisotropic zones seem to be fairly homogenous, but with a greater magnification $(e . g .1000 \times$ ) emulsions of very fine-grained inclusions in the host sphalerite can be seen (cf. Fig. 1). With oil immersion, even the lamellar form of the inclusions, running in two opposite directions, can be seen in some grains. In addition to these emulsions, there are also some larger irregular chalcopyrite inclusions in the sphalerite.

\section{Single-crystal study}

Under a binocular microscope two untwinned crystal fragments were separated from the marginal zone and one from the central part of a sphalerite crystal from the greisen-bordered veinlet north of Eurajoki. Single-crystal studies on these fragments showed that it is really a question of an intergrowth of sphalerite and chalcopyrite in the pseudoanisotropic marginal zone. The photographs taken from the isotropic central part only gave sphalerite reflections. Fig. 2 presents an $a$-axis zero-level precession photograph of a crystal fragment from the border zone. The chalcopyrite intergrowths are oriented in three crystallographically equivalent directions so that their crystallographic axes are always parallel to the sphalerite axes. The $c$ axes of the chalcopyrite inclusions are oriented parallel to the [100], [010] and [001] axes of the host sphalerite (Fig. 2) (cf. Jancović, 1957). From the precession photograph, the following unit cell dimensions were measured for the pseudoanisotropic sphalerite-chalcopyrite intergrowth:

$$
\begin{aligned}
& \text { sphalerite } a_{0}=5.412 \pm 0.005 \AA \\
& \text { chalcopyrite } a_{0}=5.307 \pm 0.005 \AA \\
& \text { chalcopyrite } c_{0}=10.374 \pm 0.010 \AA
\end{aligned}
$$

The film was calibrated with the reflections of an oriented silicon crystal, exposed on the same film. A powder photograph, taken with a $57.3 \mathrm{~mm}$ Debye-Scherrer camera and corrected for film shrinkage, gave $a_{0}=5.419 \pm 0.005 \AA$ for the isotropic sphalerite. The chemical compositions derived from the unit cell edges of these sphalerites (e.g. Barton and Toulmin, 1966) 
correspond within the limits of error to those obtained with the electron microprobe. Neither the isotropic nor the pseudoanisotropic sphalerite gave any reflections indicating the presence of a wurzite structure.

\section{Microprobe analyses}

The central part and the marginal zone of a zoned sphalerite crystal (the same grain as in Fig. 1) from Eurajoki were analysed with an electron probe microanalyser (model Geoscan). The excitation potential used was $20 \mathrm{kV}$ and the specimen current $60 \mathrm{~m} \mu \mathrm{A}$. The copper content was analysed by using a chalcopyrite crystal from the same sample as the standard, for which a theoretical value of $34.62 \% \mathrm{Cu}$ was assumed. In all the other determinations an analysed sphalerite standard was used. In order to minimize the differences in the electric conductivity the sample and the standard were coated with an aluminium film. Fig. 3 presents electron probe scanning pictures showing the distribution of $\mathrm{Cu}$ and $\mathrm{Fe}$ in the grain on which the analyses were made. The isotropic central part was analysed at three arbitrarily chosen points. No notable differences were noticed in the chemical composition. The marginal zone was analysed at points where no chalcopyrite inclusions were noticed with an optical microscope with a $160 \times$ magnification. The four main elements ( $\mathrm{Zn}, \mathrm{S}$, $\mathrm{Fe}, \mathrm{Cu}$ ) were analysed at five different points and $\mathrm{Mn}$ and $\mathrm{Cd}$ at three points.

The highest and lowest values of the main elements were discarded. All the results were corrected for background, absorption (Philibert, 1963) and fluorescence (Reed, 1965). The means of the results are presented in Table 1 . In spite of the inhomogeneous nature of the marginal zone, noted with the high magnification, the chemical composition proved to be very homogeneous. Only the highest (discarded) $\mathrm{Fe}$ and $\mathrm{Cu}$ values, 6.7 per cent and 7.7 per cent, respectivily, differed notably from the corresponding mean.
TABLE 1

Chemical composition of the zoned sphalerite, Eurajoki. Specimen 204A/IH/67. Electron probe microanalyses by K. Laajoki

\begin{tabular}{|c|c|c|c|c|}
\hline & 1 & 2 & $1 \mathrm{a}$ & $2 \mathrm{a}$ \\
\hline $\mathrm{Zn} \ldots \ldots \ldots \ldots \ldots$ & 54.1 & 53.4 & 0.81 & 0.80 \\
\hline $\mathrm{Fe} \ldots \ldots \ldots \ldots \ldots$ & 11.6 & 6.4 & 0.20 & 0.11 \\
\hline $\mathrm{Cu} \ldots \ldots \ldots \ldots \ldots$ & 0.5 & 7.2 & 0.01 & 0.11 \\
\hline $\mathrm{Mn} \ldots \ldots \ldots \ldots \ldots$ & 0.1 & 0.0 & 0.00 & 0.00 \\
\hline $\mathrm{Cd} \ldots \ldots \ldots \ldots \ldots$ & 0.3 & 0.3 & 0.00 & 0.00 \\
\hline \multirow[t]{2}{*}{ s $\ldots$} & 32.8 & 32.6 & 1.00 & 1.00 \\
\hline & 99.4 & 99.9 & 2.02 & 2.02 \\
\hline
\end{tabular}

1. Central part (weight per cent)

2. Marginal zone (weight per cent)

$1 \mathrm{a}$ and $2 \mathrm{a}$. Number of ions calculated from the analyses 1 and 2 on the basis of 1 (S)

These high values are probably due to unusually large or abundant chalcopyrite inclusions. The atomic ratio $\mathrm{Cu}: \mathrm{Fe}$ is 0.99 in the marginal zone. Thus it is evident that the iron in the marginal zone is included in the chalcopyrite. The $\mathrm{Zn}$ content is nearly the same in different zones of the sphalerite (Table 1). The essential compositional difference between the zones is that the FeS (19.2 mole per cent, 17.5 weight per cent) of the central part is replaced by $\mathrm{CuFeS}_{2}(12.1$ mole per cent, 20.5 weight per cent) in the marginal zone.

\section{Discussion}

The origin of the isotropic-pseudoanisotropic zoning in sphalerite is discussed by Maucher and Rehwald (1962, No. 0204) thus: "The zonal structure in the sphalerite ... is not growth zoning but rather »exsolution zoning», probably caused by tension at the more rapidly cooled grain borders». And further: »It is still in question whether the small inclusions are really »exsolutions» or whether they consist of later infiltrations» (op. cit., No. 0204). In both of the described Eurajoki occurrences, chalcopyrite 
is the principal ore mineral and it is, at least for the most part, clearly younger than sphalerite. Because the activity of sulfur is not known in the occurrences, the sphalerite geothermometer based on $\mathrm{ZnS}-\mathrm{FeS}$ composition is only of very limited if of any value (e.g. Kullerud, 1953; Boorman, 1967). However, for the composition of the central part of the sphalerite (19.2 mole per cent $\mathrm{FeS}$ ) the curves presented by Sims and Barton (1961, p. 1222) and by Boorman (1967, p. 622) give temperatures of $\sim 600^{\circ} \mathrm{C}$ and $\sim 650^{\circ} \mathrm{C}$ or lower, respectively. These temperatures are not corrected for the confining pressure. According to Donnay and Kullerud, (1958) 10 weight per cent $\mathrm{CuFeS}_{2}$ in the sphalerite exceeds the solubility limit at $600^{\circ} \mathrm{C}$. The marginal zone of the Eurajoki sphalerite contains 20.5 weight per cent $\mathrm{CuFeS}_{2}$, but it is not clear whether the very small chalcopyrite inclusions are formed by exsolution (cf. e.g. Jancović, 1968). At Eurajoki the pseudoanisotropic sphalerite sometimes intersects the isotropic central part along fissures thus proving that the zonal structure is not primary growth zoning but a secondary phenomenon. The mechanism of the zone formation is not clear. It is difficult to consider the zonal structure as formed entirely by internal diffusion in the sphalerite crystal, without any material exchange with the surrounding substances. It is possible, that the pseudoanisotropic zones were formed by the addition of $\mathrm{Cu}$ from the outside (largely by the replacement of $\mathrm{FeS}$ with $\mathrm{CuFeS}_{2}$ ) at elevated temperatures after the crystallization of the host sphalerite (cf. Ramdohr, 1924, p. 6; and 1953, p. 441. point 5). The chalcopyrite emulsions could have been formed by exsolution during the subsequent cooling or by direct diffusion and replacement without at any time being completely in solid solution with the sphalerite. An analogous instance is described by Ramdohr (1960, Fig. 395) from Hunan, China, where a stannite crystal, bordering on chalcopyrite, contains at the grain margins a zone of lamellar chalcopyrite intergrowths, which are explained as having been produced by replacement. It is possible that the tension at the grain borders, pointed out by Maucher and Rehwald (1962) has had a notable significance in these processes.

Acknowledgements - The authors are grateful to Mr. Erkki Halme for taking the photograph. Thanks are also due to Mr. Jaakko Siivola, Lic. Phil., and to Dr. Atso Vorma for kindly reading the manuscript.

\section{REFERENCES}

Barton, P. B. and Toulmin, P., III (1961) Phase relations involving sphalerite in the $\mathrm{Fe}-\mathrm{Zn}-\mathrm{S}$ system. Econ. Geol. 61, pp. 333-353.

Boorman, R. S. (1967) Subsolidus studies in the ZnS-FeS-FeS ${ }_{2}$ system. Econ. Geol. 62, pp. 614-631.

Donnay, G. and Kullerud, G. (1958) High-temperature chalcopyrite. Carnegie Inst. Washington, Ann. Rep. Dir. Geophys. Lab., 1957-1958, vol. 57, p. 246. JANCOviĆ, S. (1957) Verwachsungstrukturen zwischen Zinkblende und Kupferkies auf jugoslavischen Lagerstätten. Neues Jahrb. Mineral., Abh., 90, pp. 241 -252 .

Kullerud, G. (1953) The FeS-ZnS system. A geologic thermometer. Norsk geol. tidskr. 32, pp. 61-147.

Maucher, A. and Rehwald, G. (editors) (1962). Card index of ore photomicrographs, Nos. 0204-0205. Umschau Verlag, Frankfurt am Main, West Germany. Philibert, J. (1963) A method for calculating the absorption correction in electron-probe microanalysis. X-ray Optics and X-ray Microanalysis, p. 379. Edited by Pattee, H. H., Cosslett, V. E., and Engström, A. Academic Press, New York.

Ramdohr, P. (1924) Beobachtungen an opaken Erzen. Arch. Lagerstättenforschung, H. 34.

- (1953) Mineralbestand, Strukturen und Genesis der Rammelsberg - Lagerstätte. Geol. Jahrb. 67, pp. $367-494$.

- (1960) Die Erzmineralien und ihre Verwachsungen. Third edition, Academie-Verlag, Berlin.

ReED, S. J. B. (1965) Characteristic fluorescence correc- 
tions in electron-probe microanalysis. Brit. J. Appl. Phys. 16.

SAKSELA, M. (1951) Zur Mineralogie und Entstehung der Pitkäranta-Erze. C. R. Soc. géol. Finlande 24, Bull. Comm. géol. Finlande 154, pp. 181-232.
Sims, P. K. and Barton, P. B. (1961) Some aspects of the geochemistry of sphalerite, Central City district, Colorado. Econ. Geol. 56, pp. 1211-1237.

Manuscript received, September 20, 1968. 